\title{
Ocena zmian toksyczności gleby skażonej niklem i substancjami ropopochodnymi w procesach fitoremediacji
}

\begin{abstract}
W artykule omówiono zagadnienia związane z oczyszczaniem gleb skażonych niklem i substancjami ropopochodnymi. Do oczyszczania skażonej gleby wytypowano technologię opartą na fitoremediacji wykorzystującej aktywność roślin z grupy hiperakumulatorów i naftofitów (Lettuce iceberg, Melilotus officinalis, Festuca arundinacea) do pobierania zanieczyszczeń przez system korzeniowy. Na podstawie badań laboratoryjnych określono zarówno wpływ rodzaju fitoremedianta na proces oczyszczania gleby, jak i oddziaływanie obecności substancji ropopochodnych na proces oczyszczania gleby zanieczyszczonej niklem. Podjęcie się realizacji tego zadania wymagało wykorzystania metod badawczych obejmujących analizy fizykochemiczne i badania toksykologiczne gleb, do przeprowadzenia których zastosowano mikrobiotesty typu ToxKit. Po zakończeniu 6-miesięcznego procesu fitoremediacji wykonano analizę chemiczną materiału roślinnego, celem określenia zawartości niklu w części naziemnej i korzeniu wytypowanych do badań fitoremediantów. Na podstawie uzyskanych wyników sformułowano wnioski dotyczące zagadnień związanych z zastosowaniem fitoremediacji w procesie oczyszczania skażonych gleb w zależności od stężenia i rodzaju substancji toksycznej. Ponadto określono, jakie rośliny spośród badanych są najlepiej przystosowane do wzrostu na skażonym terenie oraz jaki wymierny skutek obniżenia zanieczyszczeń przy ich wzroście można osiągnąć.
\end{abstract}

Słowa kluczowe: fitoremediacja, gleba skażona, nikiel, substancje ropopochodne, testy toksykologiczne.

\section{Evaluation of toxicity changes in soil contaminated with nickel and petroleum-derived substances in phytoremediation processes}

\begin{abstract}
The article discusses issues related to cleaning of soils contaminated with nickel and petroleum-derived substances. Technology based on phytoremediation process that exploits activity of plants from the hyperaccumulator and petroleum-resistant plants group (Lettuce iceberg, Melilotus officinalis, Festuca arundinacea) was selected to clean the soil. Based on laboratory tests the impact of both the type of phytoremediation on the process of cleaning the soil, as well as the impact of the presence of oil on the process of cleaning soil contaminated with nickel was determined.This task requires the use of research methods such as physiochemical analysis and soil toxicological studies that utilize ToxKit microbiotests. Biomass chemical analysis in order to determine the nickel content in the aerial parts and roots was performed at the end of a 6-month process. Based on the obtained results conclusions related to the application of phytoremediation in soil remediation cleaning process depending on the concentration of toxic substance were edited. The types of plants that best adapt to growing in the contaminated area and reduction in the level of contamination due to their growth was also described in the article.
\end{abstract}

Key words: phytoremediation, contaminated soil, nickel, petroleum-derived substances, toxicological tests.

\section{Wstęp}

Pogłębiająca się świadomość znaczenia gleby jako elementu środowiska nakłania do dbałości o utrzymanie lub poprawę jej możliwości wykonywania swoich funkcji. Gleba bowiem nie jest zasobem niewyczerpalnym i, jeśli 
niewłaściwie jest używana lub źle zarządzana, jej właściwości mogą zostać utracone w krótkim czasie, przy ograniczonych możliwościach regeneracji.

Gwałtowny rozwój działalności przemysłowej sprzyja degradacji środowiska naturalnego, która jest związana m.in. z nadmierną akumulacją szkodliwych substancji, takich jak metale ciężkie czy węglowodory (głównie ropopochodne), w ekosystemach wodnych i glebowych [6]. Do zanieczyszczania środowiska omawianymi składnikami dochodzi zarówno w wyniku naturalnie zachodzących w przyrodzie procesów, jak i na skutek uwalniania ich do środowiska w ramach różnych działań antropogenicznych, takich jak: górnictwo, działalność przemysłowa, galwanizacja, obróbka osadów ściekowych, rolnictwo, motoryzacja $[1,3,4,7,8,9,11]$. Duże, przekraczające dopuszczalne normy, nagromadzenie się zarówno węglowodorów, jak i metali ciężkich w glebie negatywnie wpływa na wegetację roślin oraz pozostałe organizmy obecne w takim ekosystemie.

Występowanie metali ciężkich i substancji ropopochodnych w glebie, będącej tworem dynamicznym, stwarzającym warunki do egzystencji roślin, może spowodować naruszenie jej właściwości biochemicznych oraz składu jakościowego i ilościowego pierwiastków śladowych, co z kolei może przyczyniać się do jej degradacji.

W przywracaniu wartości użytkowych terenów zdegradowanych coraz większe znaczenie odgrywają metody remediacyjne, wykorzystujące naturalną aktywność roślin do pobierania przy wzroście składników zanieczyszczających środowisko naturalne. Metody fitoremediacyjne są bezpieczne, skuteczne, a ponadto ekonomicznie uzasadnione, w porównaniu z innymi technologiami [2].
Zawartość w glebach metali ciężkich czy substancji ropopochodnych w nadmiernych ilościach jest toksyczna dla wzrostu poszczególnych gatunków roślin. Związki te ograniczają wzrost roślin, prowadzą do różnego rodzaju nekroz, a w konsekwencji - do obumierania poszczególnych tkanek. Są jednak gatunki, które tolerują znaczne ilości substancji niebezpiecznych, a czasem dzięki nim lepiej się rozwijają [5]. Znane są gatunki gromadzące $1 \div 2 \%$ metali w tkankach (hiperakumulatory) oraz rośliny zdolne do wzrostu na glebach zanieczyszczonych substancjami ropopochodnymi (naftofity). Rośliny te absorbują, kumulują i metabolizują węglowodory wchodzące w skład ropy naftowej.

Wysokie zawartości zanieczyszczeń w glebach w znaczący sposób mogą wpływać na ekosystemy, powodując zmiany w funkcjach poszczególnych gatunków organizmów. Działania niepożądane ksenobiotyków i ich metabolitów na organizmy żywe mogą być oceniane na podstawie obserwacji reakcji bioindykatorów na dany rodzaj zanieczyszczenia. Wewnątrz bioindykatorów zachodzą bowiem procesy biochemiczne, których rezultatem mogą być: zmiany morfologiczne ciała, choroby, a w końcu - śmierć. Takie bioindykatory wykorzystano w mikrobiotestach typu ToxKit. Testy te wykorzystują organizmy przechowywane w stadium uśpienia lub unieruchomienia (formy kryptobiotyczne), które po przeprowadzeniu prostej procedury uwolnienia mogą służyć do określanie stopnia toksyczności m.in. gleb [10].

Badania opisane w niniejszym artykule ukierunkowano na poszukiwanie i selekcję roślin z grupy hiperakumulatorów i naftofitów, mających wymierny wpływ na obniżenie w skażonych glebach zarówno ilości metali ciężkich, jak i substancji ropopochodnych.

\section{Materiał i metodyka badawcza}

Materiał badawczy stanowiła gleba pobrana z użytku rolnego, w której zoptymalizowano zawartość składników biogennych. $\mathrm{Z}$ gleby tej przygotowano próbki glebowe zanieczyszczone:

- substancjami ropopochodnymi (ropa naftowa kondycjonowana w temperaturze $260^{\circ} \mathrm{C}$ ) w ilości $10 \mathrm{~g} / \mathrm{kg} \mathrm{s.m}$. gleby - gleba A,

- niklem w stężeniu $500 \mathrm{mg} / \mathrm{kg}$ s.m. gleby - gleba B,

- substancjami ropopochodnymi w ilości $10 \mathrm{~g} / \mathrm{kg}$ s.m. gleby oraz niklem w stężeniu $500 \mathrm{mg} / \mathrm{kg}$ s.m. gleby - gleba C.

Badanymi fitoremediantami były rośliny mające zdolność akumulacji metali ciężkich (hiperakumulatory) oraz rośliny z grupy tzw. naftofitów, posiadające podczas wzrostu wysoką tolerancję na obecność zanieczyszczeń ropopochodnych w gruncie: sałata (Lettuce iceberg), nostrzyk żólty (Melilotus officinalis) oraz kostrzewa trzcinowa (Festuca arundinacea).
Próbki glebowe pobrano z trzech miejsc warstwy powierzchniowej, z głębokości $0 \div 30 \mathrm{~cm}$ ppt. Po przewiezieniu do laboratorium próbki gleby uśredniono, po czym oznaczono wilgotność poprzez określenie ubytku masy gleby, będącego efektem odparowania wody podczas suszenia $\mathrm{w} 105^{\circ} \mathrm{C}$.

Pozostałą część gleby doprowadzono do stanu powietrznie suchego, przesiano przez sito o wielkości oczek $1 \mathrm{~mm}$ i wykonano jej analizę fizykochemiczną.

Izolację oznaczanych analitów z matrycy glebowej wykonano poprzez:

- ekstrakcję TPH z gleby za pomocą dichlorometanu w aparacie Soxhleta,

- ekstrakcję substancji rozpuszczalnych w wodzie (w proporcji gleby do wody $=1: 10 \mathrm{~m}: \mathrm{m}$ ),

- mineralizację gleby w stężonym roztworze $\mathrm{HNO}_{3} \mathrm{w}$ mikrofalowym mineralizatorze Magnum II. 
Zawartość substancji organicznych, ekstrahujących się dichlorometanem, oznaczono metodą wagową po odparowaniu rozpuszczalnika. Wodny ekstrakt gleby analizowano pod kątem wartości parametrów fizykochemicznych, takich jak: odczyn $\mathrm{pH}$, przewodność oraz zawartość kationów: $\mathrm{K}^{+}$, $\mathrm{NH}_{4}{ }^{+} \mathrm{i}$ anionów: $\mathrm{Cl}^{-}, \mathrm{NO}_{3}^{-}, \mathrm{PO}_{4}^{3-}$ oraz $\mathrm{SO}_{4}{ }_{4}^{2-}$.

Wyizolowane na drodze mineralizacji składniki gleby badano pod kątem zawartości niklu oraz wapnia i magnezu.

Odczyn roztworu wodnego gleb oznaczono metodą potencjometryczną, natomiast aniony i kationy odpowiednią metodyką chromatograficzną z wykorzystaniem chromatografu jonowego firmy Sycam. Przed uruchomieniem każdej nowej metody analitycznej konfigurowano chromatograf, wykonując odpowiednie połączenia kolumn i detektorów, po czym wyznaczano krzywe kalibracyjne poszczególnych składników, stosując certyfikowane roztwory wzorcowe anionów i kationów.

Badana gleba, po doprowadzeniu zawartości składników biogennych do wartości optymalnych (poprzez dozowanie nawozu mineralnego Azofoska), posłużyła do przygotowania próbek gleb skażonych znanymi dawkami: soli niklu, substancji ropopochodnych, oraz próbek gleby skażonej zarówno znanymi dawkami soli niklu, jak i substancji ropopochodnych.

Tak przygotowane gleby poddano testowi Phytotoxkit w celu stwierdzenia możliwości wzrostu testowanych roślin. Do badań wykorzystano zarówno rośliny zalecane przez producenta testu (Sorghum saccharatum, Lepidium sativum, Sinapis alba), jak i rośliny wytypowane przez autorów przeprowadzanego eksperymentu oczyszczania gleb (Lettuce iceberg, Melilotus officinalis, Festuca arundinacea), charakteryzujące się dużą przenikalnością pierwiastków przez system korzeniowy.

Kolejnym etapem badań było utworzenia stanowiska uprawy wazonowej poszczególnych gatunków roślin w glebach: niezanieczyszczonej oraz zanieczyszczonych znanymi dawkami toksykantów. Eksperyment prowadzono w warunkach laboratoryjnych, a przez okres jego trwania utrzymywano dogodne warunki rozwoju roślin, poprzez odpowiednie ich nawadnianie.

Procesowi fitoremediacji skażonych gleb towarzyszył monitoring ich składu, zarówno pod względem zawartości niklu, jak i substancji ropopochodnych. Izolacji oznaczanych zanieczyszczeń gleb dokonano w początkowej fazie eksperymentu, a następnie po 1, 4 i 6 miesiącach jego trwania. Ponadto po zakończeniu procesu fitoremediacji wykonano analizę materiału roślinnego (części naziemne oraz korzenie), który po zmineralizowaniu badano pod kątem zawartości jonów niklu. Równolegle z czasem trwania eksperymentu (w pierwszym i szóstym miesiącu) zostały przeprowadzone testy fitotoksykologiczne gleb: Phytotoxkit, Spirodela Duckweed Toxkit oraz Ostracodtoxkit $F^{T M}$.

Phytotoxkit należy do testów oceny toksyczności ostrej i jest oparty na ocenie kiełkowania i wczesnego wzrostu roślin. W standardowym teście używane są 3 rodzaje roślin wyselekcjonowanych ze względu na szybkość kiełkowania i szybkość wzrostu korzeni, co umożliwia wykonanie pełnego oznaczenia w ciągu 3 dni inkubacji: jednoliścienne - sorgo (Sorghum saccharatum), dwuliścienne - rzeżucha (Lepidium sativum) i gorczyca (Sinapis alba).

Do celów realizacji badań fitotoksyczności gleb zanieczyszczonych test Phytotoxkit przeprowadzono również dla fitoremediantów: Lettuce iceberg, Melilotus officinalis oraz Festuca arundinacea. Oznaczenia te przeprowadzano w 3 powtórzeniach dla każdej testowej rośliny. Badania wykonywano w polistyrenowych, przezroczystych płytkach testowych.

Stworzono następujące warunki inkubacji: temperatura $T=25^{\circ} \mathrm{C}$ w ciemności, czas inkubacji $t=72 \mathrm{~h}$. Reakcja testowa polegała na zahamowaniu kiełkowania oraz wczesnego wzrostu korzenia.

Mikrobiotest oceny toksyczności Spirodela Duckweed Toxkit jest testem zahamowania (lub braku) wzrostu wodnych roślin wyższych Spirodela polyrhiza. Pozwala on ocenić hamowanie wzrostu kiełkujących turionów, po 3 dniach ekspozycji na substancje toksyczne w odniesieniu do kontroli, która przebiega w nietoksycznej pożywce. Wzrost roślin określany jest poprzez pomiar powierzchni pierwszych liści w czasach $t=0 \mathrm{~h}$ i $t=72 \mathrm{~h}$, przy użyciu programu do komputerowej analizy obrazu. Na podstawie otrzymanych wyników obliczono zahamowanie wzrostu roślin (EC50-72h).

Badania przeprowadzono w 48-dołkowej mikropłytce, w 5 stężeniach badanego toksykanta (ekstrakty wodne gleb), każde $\mathrm{w} 8$ powtórzeniach.

Kryterium uznania testu za ważny jest wartość średniego wzrostu pierwszych listków w dołkach w rzędzie kontroli po 3 dniach inkubacji w $25^{\circ} \mathrm{C}$, przy oświetleniu 6000 lux (średnia t72h-t0k), wyższa lub równa wartości $10 \mathrm{~mm}^{2}$.

Ostracodtoxkit $F^{T M}$ należy do testów bezpośredniego kontaktu oceny toksyczności chronicznej z wykorzystaniem młodych dennych skorupiaków Heterocypris incongruens (małżoraczków) wylęgłych z cyst przetrwalnikowych w ciągu 52 godzin (zgodnie z procedura producenta). Po 6 dniach przechowywania $\mathrm{w}$ badanym osadzie określana jest ich śmiertelność i zahamowanie wzrostu wyrażone procentowo w odniesieniu do rezultatów uzyskanych w kontakcie z nietoksycznym osadem kontrolnym. Test przeprowadzany jest na płytkach z 6 dołkami $(3 \times 2)$, czas inkubacji: 6 dni w temperaturze $25^{\circ} \mathrm{C}$.

Na podstawie uzyskanych wyników przeprowadzonego eksperymentu sformułowano wnioski dotyczące zagadnień 
związanych z zastosowaniem fitoremediacji w procesie oczyszczania skażonych gleb w zależności od stężenia i rodzaju substancji toksycznej. Ponadto określono, jakie rośliny spośród badanych są najlepiej przystosowane do wzrostu na skażonym terenie oraz jaki wymierny skutek obniżenia zanieczyszczeń przy ich wzroście można osiągnąć.

\section{Wyniki badań}

Zanieczyszczenia wprowadzone do gleb wywołują interakcje z jej środowiskiem, zmieniając je pod względem chemicznym, fizycznym oraz wpływając na zachwianie równowagi biologicznej. Skutkiem tych zmian może być obniżenie żyzności gleb czy też, w najbardziej skrajnych przypadkach, degradacja. Odporność gleby na degradację spowodowaną obecnością zanieczyszczeń zależy od wielu czynników, między innymi: właściwości fizykochemicznych gleby, stężenia i jakości chemicznych zanieczyszczeń, zawartości związków biogennych (azotu, fosforu), odczynu (pH) gleby, obecności związków organicznych, składu ilościowego i jakościowego mikroorganizmów obecnych w glebie [12-16]. Czynniki te wpływają również na proces samooczyszczania skażonych gleb, który na ogół zachodzi bardzo wolno, może trwać nawet setki lat.

Użyta w eksperymencie gleba (przed dodaniem określonych zanieczyszczeń) charakteryzowała się odczynem

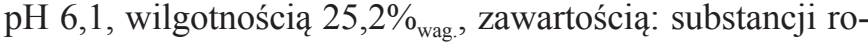
popochodnych (178 mg/kg s.m.), niklu (10,8 mg/kg s.m.), wapnia (400 mg/kg s.m.) i magnezu (61 mg/kg s.m.) oraz składników biogennych: potasu (23,2 mg/kg s.m.), azotu (23 mg/kg s.m.), fosforu (33 mg/kg s.m.). Ponadto w glebie oznaczono chlorki w ilości $286 \mathrm{mg} / \mathrm{kg}$ s.m. oraz siarczany na poziomie $154 \mathrm{mg} / \mathrm{kg} \mathrm{s.m}$.

Niski poziom składników biogennych w badanej glebie mógłby spowodować zarówno niedobór składników odżywczych dla uprawianej roślinności, jak i zahamowanie procesów mikrobiologicznych. Korektę zawartości tych składników w glebie przeprowadzono z użyciem Azofoski, w oparciu o wyniki testu fitotoksyczności. Optymalny poziom składników biogennych w glebach ma ogromne znaczenie podczas prowadzenia procesu fitoremediacji w oczyszczaniu gleb skażonych. Szybkość procesu biodegradacji jest limitowana

\section{Lepidium sativum}

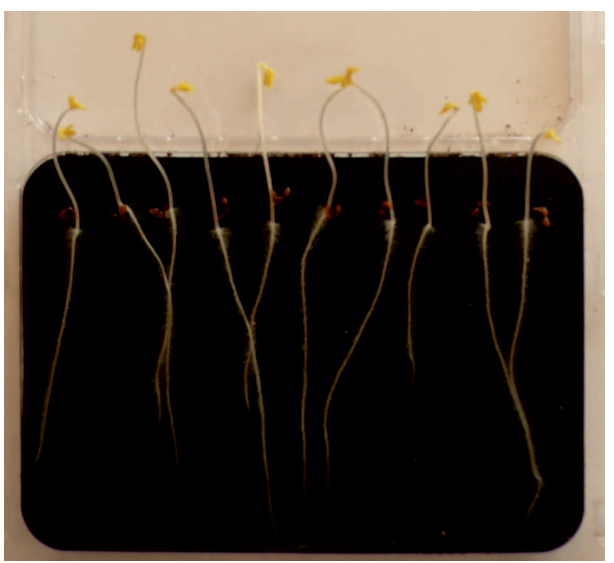

Lettuce iceberg

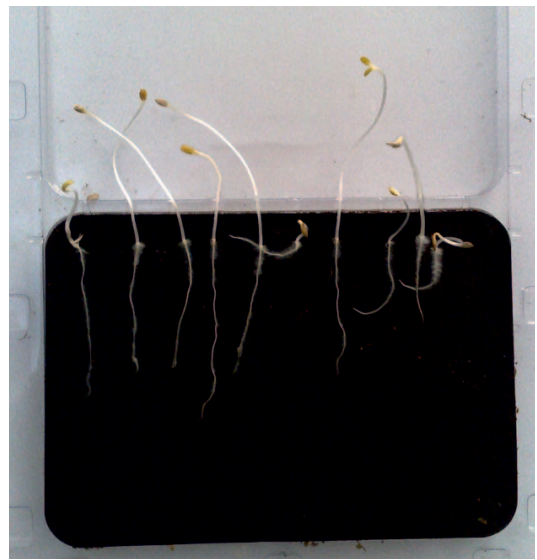

Sorghum saccharatum

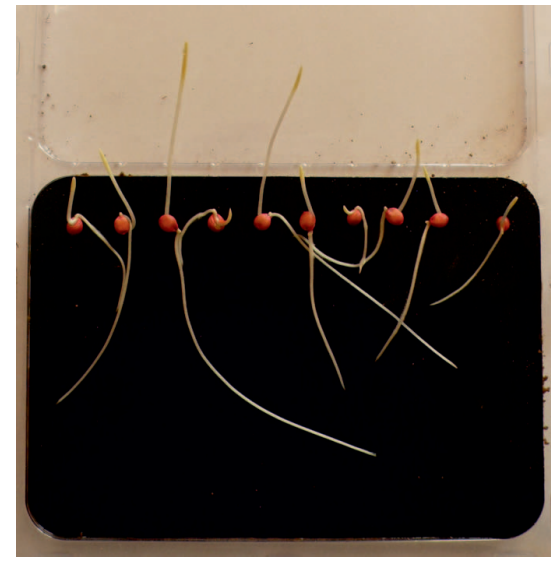

Płytki testowe z glebą z nawozami

Melilotus officinalis

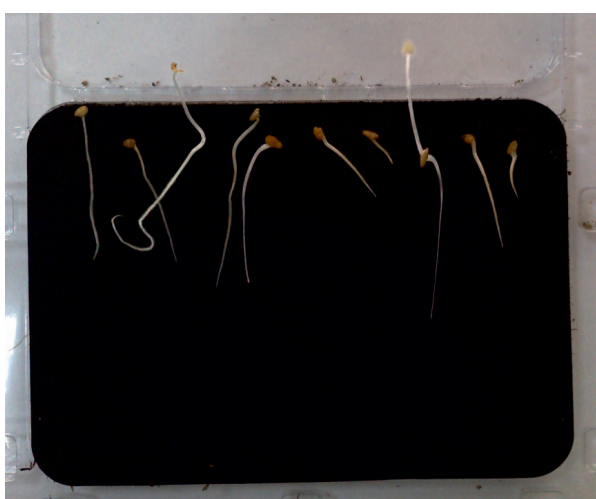

Sinapis alba

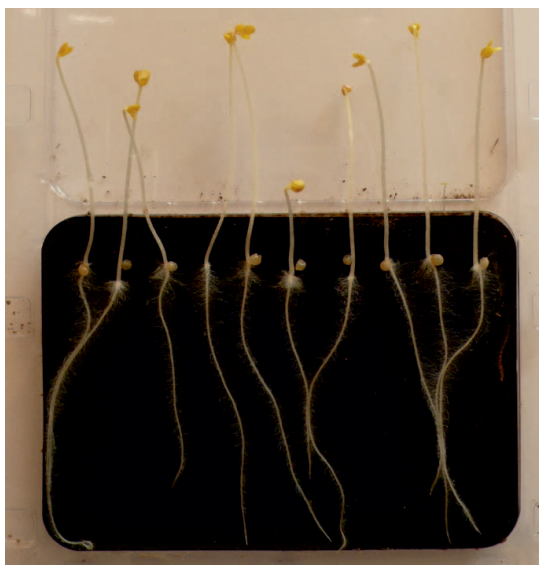

Festuca arundinacea

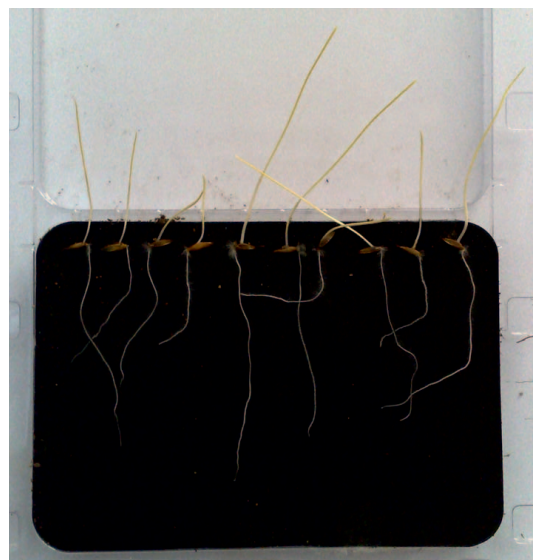

Fot. 1. Wynik testu Phytotoxkit doboru optymalnej dawki nawozów do gleby stosowanej w procesach fitoremediacji 
zawartością substancji biogennych. Ich wprowadzenie do oczyszczanego środowiska przyspiesza metabolizm mikroorganizmów rodzimych biorących udział w biodegradacji.

Testy fitotoksyczności Phytotoxkit przeprowadzono na próbkach gleby kontrolnej (gleba nieskażona) oraz użytej do procesu fitoremediacji (gleba skażona znanymi dawkami jonów niklu i substancji ropopochodnych).

W pierwszym etapie ustalono optymalne, wymagane do wzrostu roślin, zawartości składników biogennych w glebie. Do badań wykorzystano rekomendowane przez producenta testu ziarna: rzeżuchy (Lepidium Sativum), gorczycy (Sinapis alba) i sorgo (Sorghum saccharatum) (fotografia 1, tablica 1).

W kolejnym etapie badań wykonano test fitotoksyczności wzrostu ziaren roślin wytypowanych do przeprowadzenia procesu fitoremediacji skażonych gleb (fotografia 1, tablica 2).

Na podstawie wyników przeprowadzonego testu można stwierdzić, że gleba pobrana z terenu rolnego nie jest toksyczna dla wzrostu badanych roślin. W przypadku wszystkich testowanych ziaren po 3 dniach prowadzenia testu fitotoksyczności zaobserwowano prawidłowy wzrost. Ponadto wzbogacenie gleby w składniki biogenne spowodowało szybszy wzrost korzeni kiełkujących ziaren wszystkich testowanych roślin. W związku z powyższym glebę wzbogaconą w składniki biogenne zastosowano do przeprowadzenia procesu fitoremediacji zanieczyszczonego gruntu substancjami ropopochodnymi i niklem.

Przeprowadzone testy fitotoksyczności ujednoliconych próbek gleb wykazały znaczne różnice wzrostu testowanych ro- ślin w zależności od rodzaju skażenia gleby. Najbardziej odporną rośliną na testowane rodzaje zanieczyszczeń okazał się nostrzyk żółty (Melilotus officinalis), dla którego zahamowanie wzrostu korzeni było najniższe spośród testowanych roślin. Szczególnie jest to widoczne podczas jego wzrostu na glebie zanieczyszczonej substancjami ropopochodnymi (14,7\%). Pozostałe dwa testowane nasiona fitoremediantów wykazały większe zahamowanie wzrostu korzeni $(49,4 \div 76,6 \%)$. Prowadzony przez okres 6 miesięcy proces fitoremediacji zanieczyszczonych gleb spowodował spadek zawartości zanieczyszczeń w badanych glebach, czego potwierdzeniem są rezultaty ponownie przeprowadzonego testu fitotoksyczności. $\mathrm{Z}$ danych tych wynika, że dużą odpornością na zanieczyszczenia ropopochodne charakteryzowały się kostrzewa trzcinowa i nostrzyk żółty. Procent wykiełkowania nasion oznaczono w granicach: $80,0 \div 93,3 \%$, w stosunku do gleby kontrolnej. Natomiast drugi mierzony parametr - długość korzenia, po 6-miesięcznym procesie fitoremediacji $\mathrm{w}$ glebach zanieczyszczonych substancjami ropopochodnymi, uległ już nieznacznemu zahamowaniu wzrostu w stosunku do gleby kontrolnej, wynosił jedynie $1,4 \div 8,7 \%$. Rośliny te również z dobrym rezultatem poradziły sobie w oczyszczaniu gleb skażonych mieszaniną niklu i substancji ropopochodnych, gdyż zahamowanie wzrostu korzenia zmniejszyło się z zakresu $60,3 \div 81,8 \%$ do $26,3 \div 26,7 \%$, przy stopniu wykiełkowania na poziomie $70,0 \div 80,0 \%$.

Zastosowanie Lettuce iceberg w procesie fitoremediacji gleb zanieczyszczonych substancjami ropopochodnymi oraz mieszaniną niklu i substancji ropopochodnych nie przyniosło

Tablica 1. Zestawienie wyników testu Phytotoxkit przeprowadzonego na próbkach gleby pobranej $\mathrm{z}$ terenu rolniczego oraz po dodaniu do niej substancji biogennych

\begin{tabular}{|c|c|c|c|}
\hline Parametr & Próbka kontrolna & $\begin{array}{l}\text { Gleba z użytku rolnego } \\
\text { (3 powtórzenia) }\end{array}$ & $\begin{array}{l}\text { Gleba z nawozami } \\
\text { (3 powtórzenia) }\end{array}$ \\
\hline Testowany organizm & \multicolumn{3}{|c|}{ Rzeżucha (Lepidium Sativum) } \\
\hline Kiełkowanie [\%] & 100 & 100 & 100 \\
\hline Średnia długość korzenia [mm] & 53 & 65 & 79 \\
\hline Minimalna długość korzenia [mm] & 42 & 53 & 55 \\
\hline Maksymalna długość korzenia [mm] & 72 & 79 & 89 \\
\hline Testowany organizm & \multicolumn{3}{|c|}{ Sorgo (Sorghum saccharatum) } \\
\hline Kiełkowanie $[\%]$ & 100 & 100 & 100 \\
\hline Średnia długość korzenia [mm] & 44 & 37 & 55 \\
\hline Minimalna długość korzenia [mm] & 19 & 24 & 25 \\
\hline Maksymalna długość korzenia [mm] & 85 & 52 & 106 \\
\hline Testowany organizm & \multicolumn{3}{|c|}{ Gorczyca (Sinapis alba) } \\
\hline Kiełkowanie $[\%]$ & 100 & 100 & 100 \\
\hline Średnia długość korzenia [mm] & 41 & 44 & 68 \\
\hline Minimalna długość korzenia [mm] & 18 & 30 & 51 \\
\hline Maksymalna długość korzenia [mm] & 50 & 62 & 81 \\
\hline
\end{tabular}


tak spektakularnego efektu, gdyż odnotowane zahamowanie wzrostu korzenia kształtowało się na poziomie 40,3 $\div 49,8 \%$, przy $76,7 \div 86,7$-procentowym wykiełkowaniu nasion.

Z kolei zastosowanie sałaty i nostrzyka żółtego w procesie fitoremediacyjnego oczyszczania gleb z niklu przyniosło dobry skutek, osiągnięto bowiem obniżenie zahamowania wzrostu korzenia z poziomu $59,6 \div 64,4 \%$ do $25,9 \div 28,5 \%$.

Węglowodorowe składniki ropy naftowej pokrywają powierzchnię cząstek glebowych cienką warstewką izolacyjną. Węglowodory za pomocą wiązań chemicznych łączą się z organicznymi składnikami próchnicy, natomiast nieorganiczne frakcje glebowe w połączeniu z zanieczyszczeniami naftowymi mają jedynie charakter fizyczny. Ropa naftowa i jej pochodne produkty niszczą strukturę koloidalną gleby, zaburzając właściwości fizyczne pierwotne (zwięzłość, plastyczność, lepkość) i wtórne (właściwości wodne, powietrzne i cieplne) gleby; ograniczają zdolności sorpcyjne gleby, niszcząc przez to organizmy żywe środowiska glebowego.

W przypadku zanieczyszczenia gleby substancjami ropopochodnymi testowane rośliny (w eksperymentalnie prowadzonym procesie fitoremediacji) miały utrudniony dostęp do pobierania wody i soli mineralnych z podłoża. Ponadto nastąpiło upośledzenie oddychania korzeniowego, czego skutkiem było znaczne zahamowanie wzrostu zarówno systemu korze- niowego, jak i części naziemnej, co szczególnie uwidoczniło się w przypadku sałaty. Nostrzyk żółty i kostrzewa trzcinowa w zastosowanej w eksperymencie dawce doglebowej toksykanta charakteryzowały się znacznie lepszym wzrostem (tablica 2).

Test Spirodela Duckweed Toxkit, mierzący spadek (lub brak) wzrostu kiełkujących turionów po 3 dniach ekspozycji na substancje toksyczne, przeprowadzano dla ekstraktów wodnych badanych gleb, które uzyskano w wyniku dobowego kontaktu badanych gleb z wodą w stosunku 1:10 m:m. Wyniki badań odniesiono do próbki kontrolnej, prowadzonej w nietoksycznej pożywce.

Na rysunku 1 przedstawiono efekt 6-miesięcznego procesu fitoremediacji gleb zanieczyszczonych, w którym jako fitoremedianty wykorzystano: Lettuce iceberg, Melilotus officinalis oraz Festuca arundinacea. Wynik podano jako średnią arytmetyczną 8 powierzchni liści testowanej rośliny w danym stężeniu toksykanta. Przykładowe obrazy płytek testowych ze Spirodela polyrhiza w badanych ekstraktach wodnych gleby przedstawia fotografia 2 .

$\mathrm{Z}$ danych przestawionych na rysunku 3 wynika, że najwyższą toksycznością charakteryzuje się ekstrakt wodny otrzymany z gleby zanieczyszczonej jonami niklu, dla którego wyliczona wartość EC50-72h = 31,4. Świadczy to o tym, że już takie stężenie toksykanta powoduje połowiczne zahamowanie

Tablica 2. Zestawienie wyników testów Phytotoxkit wykonanych przed i po procesie fitoremediacji

\begin{tabular}{|c|c|c|c|c|c|c|c|}
\hline \multirow{3}{*}{ Parametr } & \multicolumn{7}{|c|}{ Rodzaj gleby stosowanej w procesie fitoremediacji } \\
\hline & \multicolumn{4}{|c|}{ przed procesem fitoremediacji } & \multicolumn{3}{|c|}{ po procesie fitoremediacji } \\
\hline & kontrolna & A & $\mathrm{B}$ & $\mathrm{C}$ & A & B & $\mathrm{C}$ \\
\hline Fitoremediant & \multicolumn{7}{|c|}{ Lettuce iceberg } \\
\hline Kiełkowanie [\%] & 100 & 73,3 & 60,0 & 50,0 & 80 & 76,7 & 86,7 \\
\hline Średnia długość korzenia [mm] & 33,9 & 12,1 & 7,9 & 7,8 & 24,3 & 17,0 & 20,3 \\
\hline Minimalna długość korzenia [mm] & 21,8 & 3,4 & 2,5 & 2,1 & 19,0 & 6,9 & 11,1 \\
\hline Maksymalna długość korzenia [mm] & 51,0 & 20,5 & 15,7 & 18,2 & 43,0 & 31,7 & 41,2 \\
\hline Zahamowanie wzrostu [\%] & - & 64,4 & 76,6 & 77,1 & 28,5 & 49,8 & 40,3 \\
\hline Fitoremediant & \multicolumn{7}{|c|}{ Melilotus officinalis } \\
\hline Kiełkowanie [\%] & 100 & 80,0 & 76,7 & 60,0 & 83,3 & 80,0 & 70,0 \\
\hline Średnia długość korzenia [mm] & 28,7 & 11,6 & 24,5 & 11,4 & 21,3 & 28,3 & 21,2 \\
\hline Minimalna długość korzenia [mm] & 7,8 & 3,4 & 4,7 & 2,2 & 20,9 & 20,3 & 9,1 \\
\hline Maksymalna długość korzenia [mm] & 39,0 & 33,9 & 48,6 & 25,7 & 41,1 & 52,9 & 34,8 \\
\hline Zahamowanie wzrostu [\%] & - & 59,6 & 14,7 & 60,3 & 25,9 & 1,4 & 26,3 \\
\hline Fitoremediant & \multicolumn{7}{|c|}{ Festuca arundinacea } \\
\hline Kiełkowanie [\%] & 100 & 73,3 & 93,3 & 70,0 & 90,0 & 93,3 & 80,0 \\
\hline Średnia długość korzenia [mm] & 46,7 & 8,5 & 23,6 & 8,6 & 25,2 & 42,6 & 34,2 \\
\hline Minimalna długość korzenia [mm] & 29,7 & 3,0 & 10,8 & 2,9 & 17,1 & 22,2 & 15,2 \\
\hline Maksymalna długość korzenia [mm] & 64,9 & 13,2 & 44,9 & 15,8 & 33,6 & 58,5 & 51,2 \\
\hline Zahamowanie wzrostu [\%] & - & 81,7 & 49,4 & 81,8 & 46,0 & 8,7 & 26,7 \\
\hline
\end{tabular}




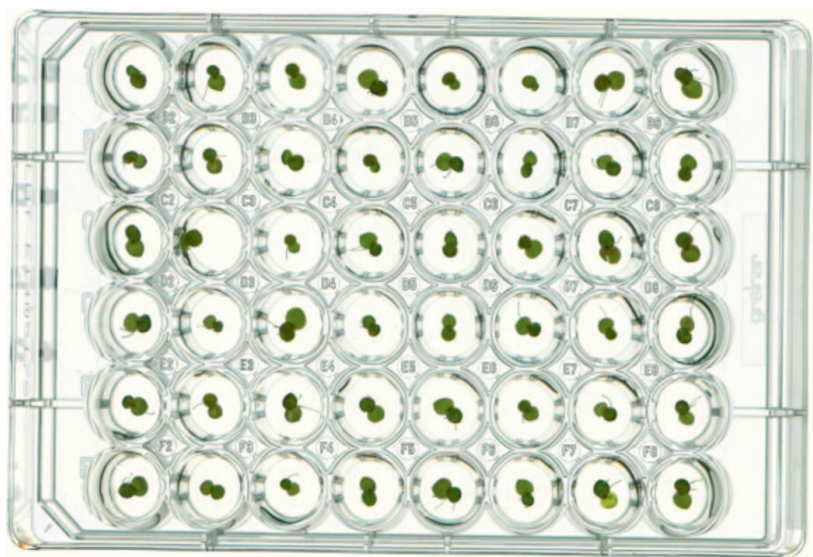

Płytka testowa t0h

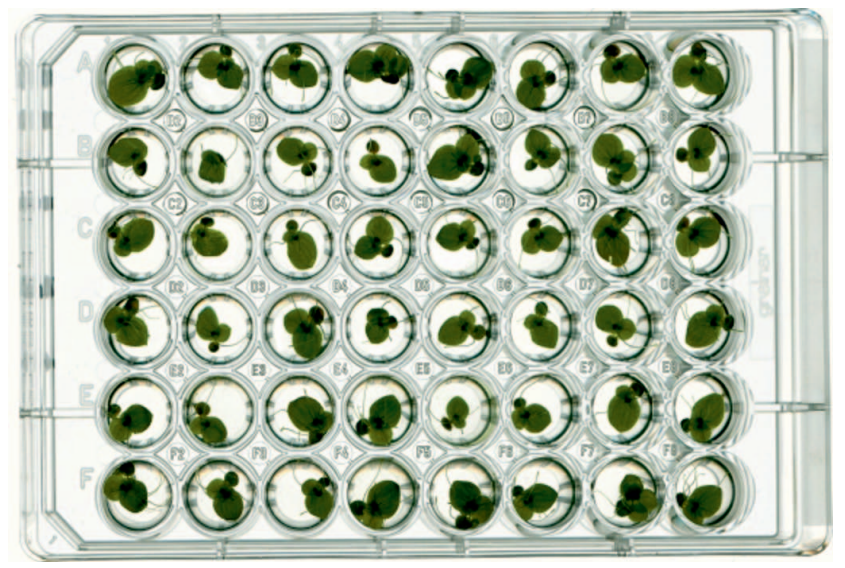

Płytka testowa $\mathrm{t} 72 \mathrm{~h}$

Fot. 2. Obraz płytek testowych ze Spirodela polyrhiza w ekstrakcie wodnym gleby kontrolnej w fazie początkowej testu (t0h) oraz końcowej (t72h)

A

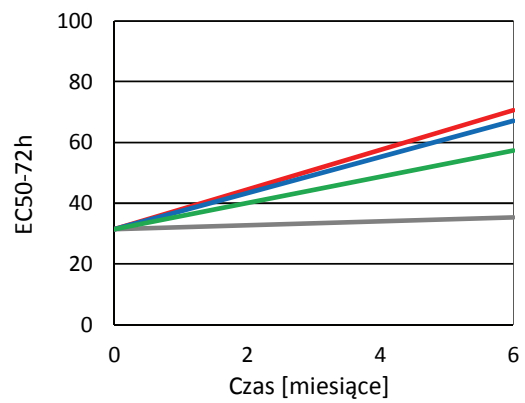

B

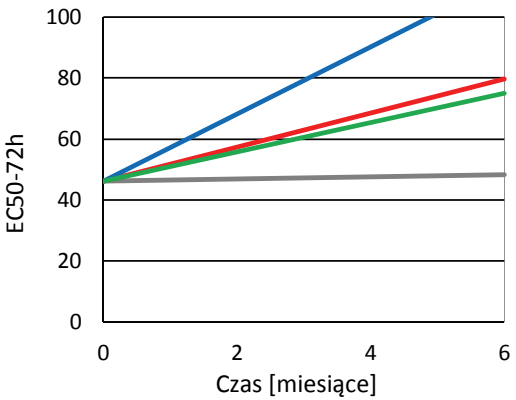

C

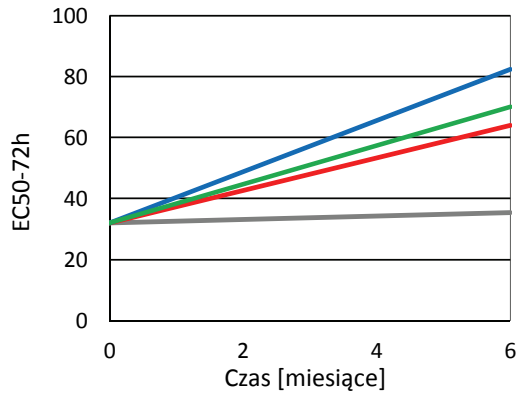

Rys. 1. Efekt procesu fitoremediacji skażonej gleby według testu Spirodela Duckweed Toxkit

A - toksykant: nikiel, B - toksykant: substancje ropopochodne, $\mathrm{C}$ - toksykant: nikiel i substancje ropopochodne — - gleba kontrolna, — - fitoremediant: Melilotus officinalis, — - fitoremediant: Lettuce iceberg, — - fitoremediant: Festuca arundinacea

wzrostu liścia Spirodela polyrhiza w porównaniu z warunkami wzrostu w środowisku pozbawionym jego zawartości.

Wartość EC50 = 46,2 (stężenie efektywne powodujące 50-procentowe zahamowanie wzrostu liścia) obliczona dla ekstraktu wodnego z gleby zanieczyszczonej substancjami ropopochodnymi jest wyższa niż dla ekstraktu z gleby zanieczyszczonej niklem. Świadczy to o wyższej toksyczności próbki gleby zawierającej nikiel niż gleby zanieczyszczonej węglowodorami.

Najniższej wartości EC50-72h, świadczącej o najwyższych toksycznych właściwościach ekstraktu wodnego, można się było spodziewać w ekstrakcie wodnym gleby skażonej największym ładunkiem zanieczyszczeń (nikiel oraz TPH). Tymczasem otrzymany wynik 32,0 wskazuje, że jest on nieznacznie wyższy od wartości EC50-72h, obliczonej dla ekstraktu gleby zanieczyszczonej jonami niklu. Uzasadnieniem takiego wyniku najprawdopodobniej może być fakt, że substancje ropopochodne w kontakcie z glebą powlekają jej ziarenka filmem, utrudniając tym samym przechodzenie składników nieorganicznych do fazy wodnej, poprzez co ekstrakt gleby staje się mniej toksyczny.
Przeprowadzone testy zahamowania wzrostu Spirodela polyrhiza, wykonane po zakończeniu 6-miesięcznego procesu fitoremediacji dla ekstraktów wodnych gleb poszczególnie oczyszczanych, wykazały skuteczność działania stosowanych fitoremediantów. Świadczy o tym wzrost wartości EC50-72h, przy których następowało 50-procentowe zahamowanie wzrostu Spirodela polyrhiza. Z przedstawionych na rysunku 1 danych wynika również to, że zanieczyszczona gleba, na której nie prowadzono wzrostu roślin w czasie trwania eksperymentu, w nieznacznym stopniu ulega samooczyszczeniu. Odnotowano wzrost wartości EC50-72h z:

- 31,4 do 35,3 - dla ekstraktu gleby zanieczyszczonej metalami ciężkimi,

- 46,6 do 48,3 - dla ekstraktu gleby zanieczyszczonej ТРН,

- 32,0 do 37,1 - dla ekstraktu gleby zanieczyszczonej metalami ciężkimi.

Analizując efekt oczyszczenia gleby zanieczyszczonej jonami niklu w procesie fitoremediacji (na podstawie przeprowadzonego testu Spirodela Duckweed Toxkit), stwierdzić można, że spośród stosowanych roślin najefektywniejszym fitoremediantem okazała się sałata (Lettuce iceberg), 
gdyż wartość EC50-72h obliczona dla ekstraktu wodnego gleby po zakończonym procesie wzrosła z 31,4 do 70,6. W przypadku pozostałych fitoremediantów osiągnięte wartości EC50-72h kształtowały się w zakresie: 57,3 $\div 67,1$.

W procesie fitoremediacji oczyszczania gleb zanieczyszczonych substancjami ropopochodnymi najkorzystniejsze wyniki otrzymano przy zastosowaniu jako fitoremedianta nostrzyka żółtego (Melilotus officinalis), gdyż ekstrakt wodny sporządzony z oczyszczonej gleby nie wykazywał toksycznych właściwości dla wzrostu Spirodela polyrhiza. Pozostałe fitoremedianty (Lettuce iceberg i Festuca arundinacea) po 6-miesięcznym procesie wzrostu spowodowały podwyższenie wartości EC50-72h ekstraktów wodnych gleb, przy których następowało 50-procentowe zahamowanie wzrostu Spirodela polyrhiza z 46,6 do zakresu: 75,0 $\div 79,7$.

Oczyszczanie gleb skażonych zarówno niklem, jak i substancjami ropopochodnymi w procesie fitoremediacji okazało się najskuteczniejsze również w przypadku wzrostu nostrzyka żółtego (Melilotus officinalis), bowiem przy zastosowaniu go jako fitoremedianta zanotowano wzrost wartości EC50-72h ekstraktu wodnego gleby z 32,0 do 82,4. Natomiast fitoremediacja prowadzona $\mathrm{z}$ wykorzystaniem wzrostu Lettuce iceberg oraz Festuca arundinacea spowodowała spadek fitotoksyczności gleby, objawiający się wzrostem wartości EC50-72h ekstraktów wodnych sporządzonych z poszczególnie oczyszczonych gleb do zakresu 64,0 $\div 70,1$ (rysunek 1).
Do badań toksyczności gleby stosowanej w procesach fitoremediacji (niezanieczyszczonej i skażonej) w charakterze biowskaźników użyto również przedstawicieli poziomu troficznego konsumentów, którymi były skorupiaki (Heterocypris incongruens). Skorupiaki te wykorzystywane są w teście Ostracodtoxikit $F^{T M}$, służącym do oceny toksyczności chronicznej, określanej na podstawie śmiertelności i hamowania wzrostu organizmów testowych (Heterocypris incongruens) po 6-dniowym kontakcie z czynnikiem środowiskowym. Wyniki testu przedstawiono w tablicy 3.

Wstępne badania gleby stosowanej w procesie fitoremediacji, dotyczące jej wpływu na skorupiaki (Heterocypris incongruens), wykazały, że gleba użyta do sporządzenia gleby zanieczyszczonej, nie wykazuje właściwości toksycznych. Średnia długość skorupiaków po 6 dniach trwania testu wynosiła $981 \mu \mathrm{m}$. Ponadto w kontakcie gleby kontrolnej z testowanymi skorupiakami odnotowano jedynie 2 przypadki śmiertelne spośród 60 testowanych osobników, co stanowi 3,3\%. Gleba zanieczyszczona niklem oraz mieszaniną niklu i substancji ropopochodnych charakteryzowała się wysoką toksycznością w kontakcie $\mathrm{z}$ testowanymi organizmami (średnia śmiertelność: 78,3 85,0\%), a średnia długość skorupiaków (żywych po 6 dniach testu) zawierała się w zakresie $367 \div 450 \mu \mathrm{m}$. Z uwagi na śmiertelność bioindykatorów, przekraczającą $50 \%$ efektu przeżyciowego, obniżenie przyrostu Heterocypris incongruens (małżoraczków) zgodnie z zalecaną

Tablica 3. Zestawienie wyników testu Ostracodtoxkit $F^{T M}$ przeprowadzonego w próbkach gleby poddawanej procesowi fitoremediacji w zależności od stosowanego fitoremedianta

\begin{tabular}{|c|c|c|c|c|c|}
\hline \multirow{3}{*}{ Parametr } & \multicolumn{5}{|c|}{ Rodzaj gleby stosowanej w procesie fitoremediacji } \\
\hline & \multirow[b]{2}{*}{ kontrolna } & \multicolumn{4}{|c|}{ gleba po 6 miesiącach procesu fitoremediacji } \\
\hline & & $\begin{array}{c}\text { bez } \\
\text { zanieczyszczeń }\end{array}$ & A & $\mathrm{B}$ & $\mathrm{C}$ \\
\hline Fitoremediant & \multicolumn{5}{|c|}{ Lettuce iceberg } \\
\hline Średnia śmiertelność [\%] & 5,0 & 6,7 & 21,7 & 25,0 & 38,3 \\
\hline Średnia długość organizmów [ $[\mu \mathrm{m}]$ & 910 & 890 & 565 & 655 & 465 \\
\hline Średni przyrost organizmów [\%] & 760 & 740 & 415 & 505 & 315 \\
\hline Średnia hamowania wzrostu [\%] & - & 2,6 & 45,4 & 33,6 & 58,6 \\
\hline Fitoremediant & \multicolumn{5}{|c|}{ Melilotus officinalis } \\
\hline Średnia śmiertelność [\%] & 5,0 & 6,7 & 13,3 & 33,3 & 36,7 \\
\hline Średnia długość organizmów $[\mu \mathrm{m}]$ & 910 & 900 & 755 & 575 & 525 \\
\hline Średni przyrost organizmów [\%] & 760 & 750 & 600 & 425 & 375 \\
\hline Średnia hamowania wzrostu [\%] & - & 1,3 & 21,1 & 44,1 & 50,7 \\
\hline Fitoremediant & \multicolumn{5}{|c|}{ Festuca arundinacea } \\
\hline Średnia śmiertelność [\%] & 5,0 & 8,3 & 20,0 & 41,7 & 43,3 \\
\hline Średnia długość organizmów $[\mu \mathrm{m}]$ & 910 & 880 & 605 & 445 & 480 \\
\hline Średni przyrost organizmów [\%] & 760 & 730 & 450 & 295 & 330 \\
\hline Średnia hamowania wzrostu [\%] & - & 3,9 & 40,8 & 61,2 & 56,6 \\
\hline
\end{tabular}


procedurą testu nie było brane pod uwagę. W stosunku do testowanych skorupiaków mniejszą toksyczność wykazała gleba zanieczyszczona substancjami ropopochodnymi, gdyż po 6 dniach wzajemnego kontaktu osiągnięto dla niej 53,3-procentowy efekt przeżyciowy małżoraczków. Średnia długość testowanych organizmów po zakończonym badaniu wynosiła $390 \mu \mathrm{m}$, co stanowi 70,9\% zahamowania wzrostu.

Wykonany test Ostracodtoxikit $F^{T M}$ na próbach glebowych oczyszczonych w wyniku prowadzenia 6-miesięcznego procesu fitoremediacji wykazał, że gleby zanieczyszczone, pozostawione jako ,ślepe próby”, nadal charakteryzowały się wysoką toksycznością dla testowanych organizmów. Średnia śmiertelność skorupiaków zmalała o 1,6 $\div 1,7 \%$ dla gleb B i C oraz o 5\% dla gleby zanieczyszczonej substancjami ropopochodnymi (gleba A).

Sześciomiesięczny wzrost roślin (Lettuce iceberg, Melilotus officinalis oraz Festuca arundinacea) na glebie niezanieczyszczonej, stosowanej do przygotowania gleb zanieczyszczonych, nie spowodował istotnego wzrostu jej toksyczności.

Przeprowadzenie procesów fitoremediacji skażonych gleb w przypadku każdego ze stosowanych fitoremediantów spowodowało obniżenie stopnia ich toksyczności. Świadczą o tym wyniki testu Ostracodtoxkit $F^{T M}$, według którego najskuteczniejszym fitoremediantem gleb skażonych niklem (gleba B) okazała się sałata (Lettuce iceberg), dzięki której osiągnięto obniżenie zanieczyszczenia gleby do takiego stopnia, że poziom śmiertelności testowanych skorupiaków zmniejszył się z 78,3 do 25,0\%. Średnie zahamowanie wzrostu testowanych małżoraczków $(33,6 \%)$ było mniejsze niż tych, które znajdowały się w glebach oczyszczonych za pomocą pozostałych testowanych roślin. Inne stosowane fitoremedianty w nieco mniejszym stopniu obniżyły stopień skażenia gleby, bo interakcja gleby oczyszczonej z testowanymi skorupiakami spowodowała zmniejszenie ich śmiertelności do zakresu: 33,6\% (Melilotus officinalis), 41,7\% (Festuca arundinacea) i zahamowanie wzrostu do poziomu $44,1 \div 61,2$.

Po przeprowadzonym procesie fitoremediacji gleby skażonej substancjami ropopochodnymi (gleba A) śmiertelność testowanych organizmów uległa zmniejszeniu z 46,7\% do poziomu: $13,3 \div 21,7 \%$, przy czym glebę z tego rodzaju zanieczyszczeń najskuteczniej oczyszczono w wyniku wegetacji Melilotus officinalis. Średnie zahamowanie wzrostu testowanych skorupiaków zmniejszyło się z 70,9\% do poziomu: 20,0\% (Melilotus officinalis), 45,4\% (Lettuce iceberg).

$\mathrm{Z}$ kolei proces fitoremediacji przeprowadzony na glebie skażonej zarówno niklem, jak i substancjami ropopochodnymi (gleba C) spowodował zmniejszenie:

- śmiertelności testowanych organizmów z 85,0\% do poziomu: $36,7 \div 43,3 \%$,

- średniej inhibicji wzrostu małżoraczków do zakresu 43,3 $358,6 \%$.

Najkorzystniejszy efekt procesu fitoremediacji gleby o najwyższym stopniu toksyczności dla testowanych małżoraczków (gleba C) uzyskano przy zastosowaniu jako fitoremedianta Melilotus officinalis. Pomimo znacznego obniżenia toksyczności gleby po 6-miesięcznym okresie prowadzenia procesu fitoremediacji, gleba ta nadal charakteryzuje się podwyższoną toksycznością dla testowanych skorupiaków, co może sugerować zbyt krótki czas prowadzenia procesu bądź też obecność metabolitów powstałych w wyniku jej oczyszczania.

Podsumowując, należy stwierdzić, że Melilotus officinalis okazał się fitoremediantem skutecznym zarówno podczas oczyszczania gleby zanieczyszczonych niklem, jak i substancjami ropopochodnymi. Zastosowanie go pozwoliło na oczyszczenie gleby do poziomu mało toksycznego dla testowanych organizmów.

Efekt sześciomiesięcznego procesu fitoremediacji gleb skażonych niklem oraz substancjami ropopochodnymi, w którym jako fitoremedianty zastosowano sałatę lodową (Lettuce iceberg), nostrzyk żółty (Melilotus officinalis) oraz kostrzewę trzcinową (Festuca arundinacea), zobrazowano na rysunku 2. Ponadto na rysunku 3 zilustrowano zawartość niklu w materiale roślinnym fitoremediantów (części naziemnej i korzeniu). Natomiast ubytek substancji ropopochodnych ze skażonych gleb, w zależności od czasu trwania procesu fitoremediacji oraz zastosowanego fitoremedianta, zobrazowano na rysunku 4.

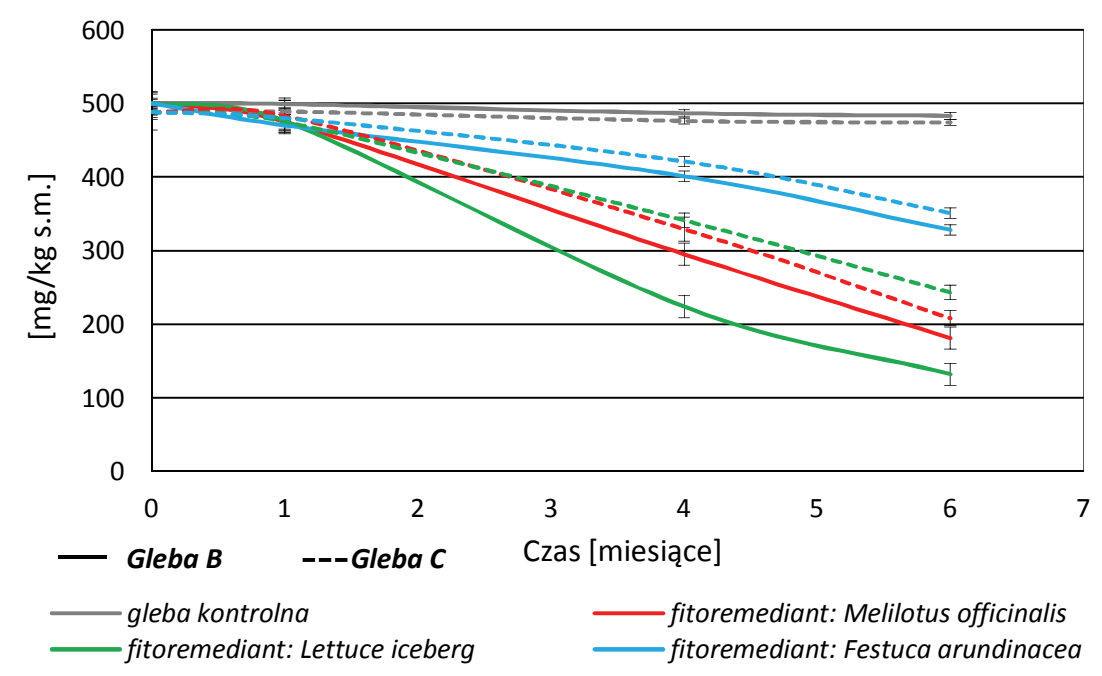

Rys. 2. Wpływ czasu prowadzenia procesu fitoremediacji oraz rodzaju fitoremedianta na obniżenie zawartości niklu w skażonych glebach 
Wyniki przeprowadzonych badań wykazały zależność szybkości ubytku toksykantów z gleb od rodzaju zanieczyszczeń oraz od użytego fitoremedianta.

Gleby zanieczyszczone metalami ciężkimi i substancjami ropopochodnymi ulegają w czasie bardzo powolnemu procesowi samooczyszczenia. Tempo oczyszczania skażonych gleb w znacznym stopniu przyspieszono w wyniku poddania ich procesowi fitoremediacji.

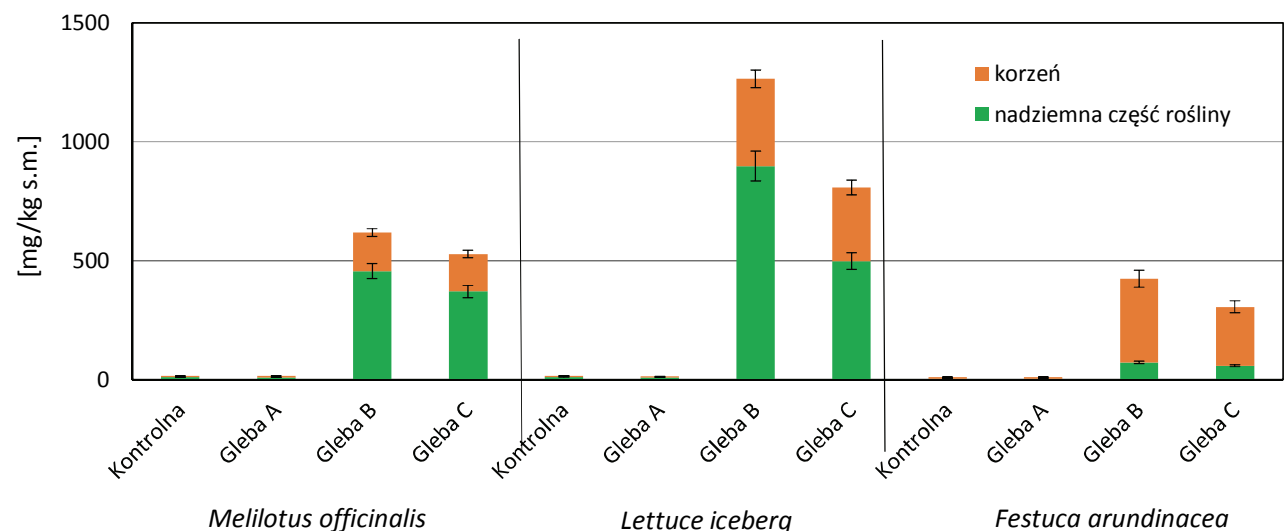

Rys. 3. Zawartość niklu w biomasie: Lettuce iceberg, Melilotus officinalis oraz Festuca arundinacea, po zakończonych procesach fitoremediacji gleb
$\mathrm{Z}$ danych przedstawionych na rysunku 3 wynika, że wyższe zanieczyszczenia gleb niklem powodują istotny wzrost jego zawartości zarówno w nadziemnych częściach roślin, jak i w korzeniach. Odnotowaną wielkość akumulacji niklu, oznaczaną w poszczególnych biomasach fitoremediantów, można uszeregować w następującej kolejności: Lettuce iceberg $>$ Melilotus officinalis $>$ Festuca arundinacea.

Lettuce iceberg oraz Melilotus officinalis akumulują nikiel w większym stężeniu w częściach nadziemnych, natomiast Festuca arundinacea - korzeniowej. Dane zobrazowane na rysunku 5 ukazują również, że obecność substancji ropopochodnych, obok niklu, w skażonych glebach wpływa na nieznaczne zmniejszenie jego zawartości w nadziemnych częściach fitoremediantów i minimalny wzrost w korzeniach.

Kolejno analizowanym aspektem procesu fitoremediacji była możliwość wykorzystania fito-
Na podstawie przeprowadzonego eksperymentu można stwierdzić, że niska zawartość niklu w glebie nieskażonej, wynikająca z naturalnej jego obecności, podczas wegetacji fitoremediantów ulega obniżeniu jedynie w niewielkim stopniu. W przypadku gleby o wyższym stężeniu niklu, którą poddano procesowi fitoremediacji, osiągnięto znacznie wyższe spadki jego zawartości w glebie wraz z czasem prowadzenia procesu. Najskuteczniejszymi fitoremediantami okazały się Lettuce iceberg oraz Melilotus officinalis, których 6-miesięczna wegetacja na glebach skażonych spowodowała obniżenie zawartości niklu z 500 mg/kg s.m. gleby do zakresu:

- $132 \div 181 \mathrm{mg} \mathrm{Ni} / \mathrm{kg}$ s.m. - w glebie zanieczyszczonej niklem (gleba B),

- $208 \div 243 \mathrm{mg} \mathrm{Ni} / \mathrm{kg} \mathrm{s.m.}-$ w glebie zanieczyszczonej niklem i substancjami ropopochodnymi (gleba C).

Zastosowanie jako fitoremedianta Festuca arundinacea $\mathrm{w}$ nieco mniejszym stopniu umożliwiło zredukowanie zawartości niklu w oczyszczanej glebie (rysunek 2).

Po zakończeniu procesu fitoremediacji skażonych gleb zebrano materiał roślinny, który - po doprowadzeniu do suchej masy zmineralizowano i oznaczono w nim zawartość niklu. Wyniki przeprowadzonych badań zilustrowano na rysunku 3. remediantów do redukcji zawartości substancji ropopochodnych skażających glebę.

Gleba nieskażona, którą wykorzystano do sporządzenia poszczególnych kompozycji gleby zanieczyszczonej, zawierała $178 \mathrm{mg}$ TPH $/ \mathrm{kg}$ s.m. Po sześciu miesiącach trwania eksperymentu w glebie nieskażonej, pozostawionej jako „gleba kontrolna", zawartość substancji ropopochodnych zmniejszyła się do $146 \mathrm{mg} / \mathrm{kg}$ s.m. W glebie będącej podłożem do wzrostu testowanych fitoremediantów odnotowano po sześciomiesięcznym okresie trwania eksperymentu wyższe ubytki mas,

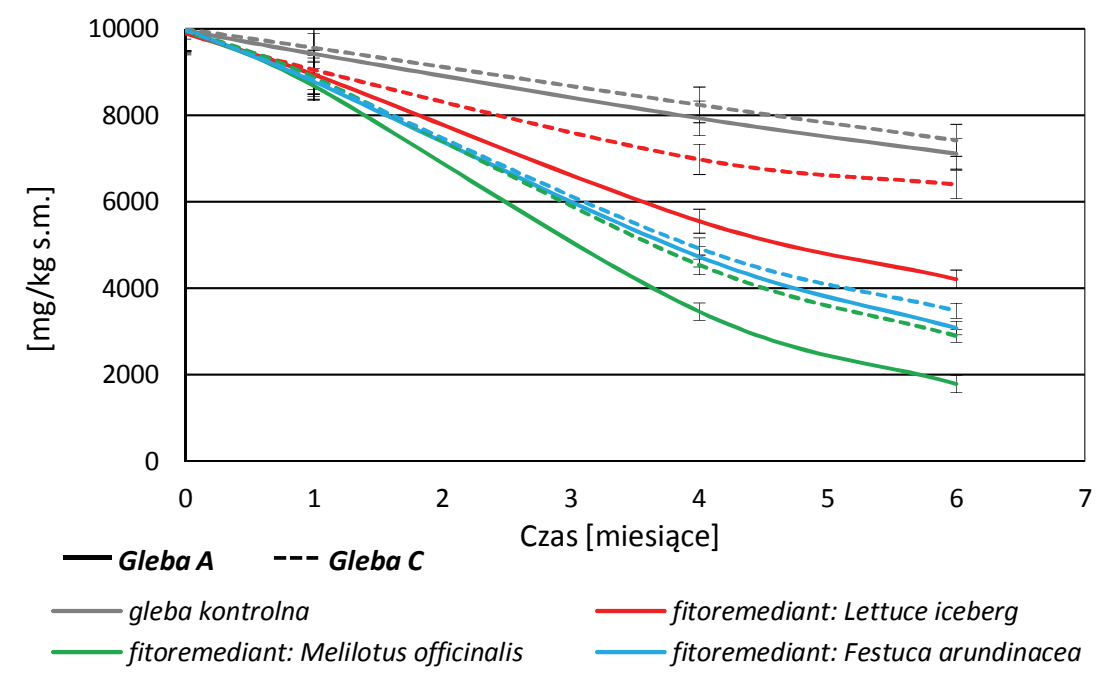

Rys. 4. Wpływ rodzaju fitoremedianta oraz czasu trwania procesu fitoremediacji na zawartość substancji ropopochodnych w zanieczyszczonej glebie 
spośród których nostrzyk żółty (Melilotus officinalis) wykazał najwyższy stopień ich redukcji, ze 178 do $56 \mathrm{mg} \mathrm{TPH} / \mathrm{kg}$ s.m. Fitoremediant ten również w przypadku gleby zanieczyszczonej niklem zredukował zawartość substancji ropopochodnych w oczyszczonej glebie do $90 \mathrm{mg}$ TPH/kg s.m.

Na rysunku 4 zilustrowano efekty prowadzenia 6-miesiecznego procesu fitoremediacji gleb zanieczyszczonych substancjami ropopochodnymi (gleba A) oraz mieszaniną substancji ropopochodnych i niklu (gleba C).

Sześciomiesięczny proces fitoremediacji gleby wstępnie skażonej $10000 \mathrm{mg}$ TPH/kg s.m. spowodował znaczną redukcję zanieczyszczeń, a mianowicie do wartości:

- $1790 \mathrm{mg} \mathrm{TPH} / \mathrm{kg}$ s.m., co stanowi 82,0\% (Melilotus officialis),

- $3480 \mathrm{mg}$ TPH/kg s.m., co stanowi 65,2\% (Festuca arundinacea)

- $4210 \mathrm{mg} \mathrm{TPH} / \mathrm{kg}$ s.m., co stanowi 57,4\% (Lettuce iceberg). Zawartość substancji ropopochodnych w glebie zanieczyszczonej $10000 \mathrm{mg}$ TPH/kg s.m., na której nie prowadzono wegetacji roślin (gleba kontrolna), po 6 miesiącach zmniejszyła się do $7110 \mathrm{mg}$ TPH $/ \mathrm{kg}$ s.m., co stanowi $28,6 \%$ (rysunek 4).

Zanieczyszczenie gleby mieszaniną niklu i substancji ropopochodnych wpłynęło na zmniejszenie efektywności usuwania zanieczyszczeń ropopochodnych ze skażonej gleby w procesie fitoremediacji. Po 6 miesiącach trwania eksperymentu ich wyjściową zawartość, wynoszącą $10000 \mathrm{mg} / \mathrm{kg}$ gleby, zredukowano o: 70,9\% (Melilotus officialis), 69,1\% (Festuca arundinacea), 35,5\% (Lettuce iceberg), 25,7\% dla gleby kontrolnej.

Z przedstawionych danych wynika, że przy zróżnicowanych formach zanieczyszczenia gleby (nikiel i substancje ropopochodne) jej proces oczyszczania jest spowolniony. Związane jest to przede wszystkim $\mathrm{z}$ większym ładunkiem zanieczyszczeń w glebie, poprzez co korzenie roślin stosowanych jako fitoremedianty mają utrudniony dostęp do składników odżywczych. Podczas prowadzenia eksperymentu w skrajnie niekorzystnych dla życia roślin warunkach zauważono również częściową nerkozę rośliny wynikającą z naruszenia jej prawidłowej gospodarki mineralnej. Zjawisko takie zaobserwowano w przypadku stosowania jako fitoremedianta sałaty, która podczas trwania eksperymentu wymagała 2-krotnego uzupełniania sadzonek.

Odmiennie zachowywała się kostrzewa trzcinowa, charakteryzująca się mocno rozwiniętym systemem korzeniowym, której zastosowanie jako fitoremedianta po 6-miesięcznym procesie fitoremediacji pozwoliło na redukcję TPH w podobnym zakresie jak w przypadku nostrzyka żółtego.

\section{Podsumowanie}

1. Proces fitoremediacji skażonych gleb, prowadzony przez okres 6 miesięcy z wykorzystaniem jako fitoremediantów roślin z grupy hiperakumulatorów (sałata - Lettuce iceberg) oraz naftofitów (nostrzyk żółty - Melilotus officinalis i kostrzewa trzcinowa - Festuca arundinacea), spowodował znaczne obniżenie ładunku zanieczyszczeń w glebach. Potwierdzają to zarówno wykonane analizy składu chemicznego gleb, jak i przeprowadzone testy toksykologiczne wykonywane na początku trwania eksperymentu i po jego zakończeniu.

2. W trakcie 6-miesięcznego trwania eksperymentu monitorowano próby glebowe pod kątem ich toksyczności oraz zawartości niklu i substancji ropopochodnych. Do badań toksykologicznych wykorzystano testy: Phytotoxkit, Spirodela Duckweed Toxkit oraz Ostracodtoxkit $F^{T M}$.

3. Najskuteczniejszymi fitoremediantami podczas oczyszczanie na drodze fitoremediacji gleb skażonych jonami niklu okazały się sałata (Lettuce iceberg) oraz nostrzyk żółty (Melilotus officinalis), natomiast gleb skażonych substancjami ropopochodnymi - nostrzyk żółty (Melilotus officinalis).

4. Podwyższone zawartości metali ciężkich w glebie powodują istotny wzrost ich ilości w wegetatywnej biomasie fitoremediantów.

5. Gleba zanieczyszczona zarówno jonami niklu, jak i substancjami ropopochodnymi wykazywała jedynie nieznacznie wyższą toksyczność dla testowanych bioindykatorów w porównaniu z glebą skażoną jonami niklu. Można sądzić na tej podstawie, że toksyczność metali jest silnie powiązana $\mathrm{z}$ ich biodostępnością.

6. Istnieje możliwość oparcia strategii likwidacji/redukcji metali ciężkich oraz substancji ropopochodnych z zanieczyszczonego terenu na fitoremediacji. Proces ten nie jest procesem technologicznym, który można wykorzystać w dowolnym miejscu i w dowolnych okolicznościach, dlatego przed jego zastosowaniem należy poznać szczegóły prowadzenia procesu, determinowane przez znajomość rodzaju i stopnia skażenia terenu oraz warunki atmosferyczne, hydrologiczne, geologiczne, charakterystyczne dla obszaru, który ma być poddany procesowi fitoremediacji. Dzięki znajomości tych parametrów możliwe będzie podejmowanie decyzji co do doboru strategicznych parametrów prowadzenia procesu fitoremediacji, którego zastosowanie umożliwi obniżenie koncentracji zanieczyszczeń obecnych $w$ gruncie do bezpiecznego poziomu. 
Prosimy cytować jako: Nafta-Gaz 2016, nr 4, s. 230-241, DOI: 10.18668/NG.2016.04.02

Artykuł nadesłano do Redakcji 23.11.2015 r. Zatwierdzono do druku 26.01.2016 r.

Artykuł zrealizowany na podstawie pracy statutowej pt. Ocena zmian toksyczności gleby skażonej metalami ciężkimi w procesach fitoremediacji - praca INiG - PIB na zlecenie MNiSW; nr zlecenia: DK-4100-0027/15; nr archiwalny: KE-4101-0027/15.

\section{Literatura}

[1] Abioye O. P.: Biological Remediation of Hydrocarbon and Heavy Metals Contaminated Soil. Earth and Planetary Sciences, Soil Contamination Edited by S. Pascucci 2011, Chapter 7.

[2] Ahn D. W., Kim S. S., Han S. J., Kim B. I.: Characteristics of Electrokinetic Remediation of Unsaturated Soil Contaminated By Heavy Metals - I: Experimental Study. The International Society of Offshore and Polar Engineers 2010, vol. 20, nr 2, s. $1053-5381$.

[3] Alkorta I., Hernandez-Allica J., Becerril J. M., Amezaga I., Albizu I., Garbisu C.: Recent findings on the phytoremediation of soils contaminated with environmentally toxic heavy metals and metalloids such as zinc, cadmium, lead, and arsenic. Reviews in Environmental Science and Bio/Technology 2004, nr 3, s. 71-90.

[4] Bossert I., Bartha R.: The fate of petroleum in soil ecosystem. R. M. Atlas (ed). Petroleum Macmillan Co, New York 1984, s. $435-476$.

[5] Gmitrzuk N.: Wpływ roślinności na rozkład substancji ropopochodnych - potencjalne możliwości w podczyszczaniu wód opadowych. Część II. Wyniki badań dotyczacych wptywu roślin na mikroorganizmy rozkładajace substancje ropopochodne - przeglad literatury. Ochrona Środowiska i Zasobów Naturalnych 2012, vol. 52.

[6] Holliger C., Gaspard S., Glod G., Heijman C., Schumacher W., Schwarzenbach R. P., Vazquez F.: Contaminated environment in the subsurface and bioremediation: Organic contaminants. FEMS Microbiology Reviews 1997, vol. 20, nr 3-4, s. 517-523.

[7] Hung-Yu Lai, Shaw-Wei Su, Horng-Yuh Guo, Zueng-Sang Chen: Heavy Metals Contaminated Soils and Phytoremediation Strategies in Tajwan. Earth and Planetary Sciences, Soil Contamination edited by S. Pascucci 2011, Chapter 6 .

[8] Łuksa A., Mendrycka M., Stawarz M.: Bioremediacja gleb zaolejonych z wykorzystaniem sorbentów. Nafta-Gaz 2010, nr 9, s. 810-818.

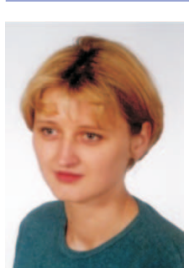

Mgr inż. Dorota KLUK

Starszy specjalista badawczo-techniczny w Zakładzie Technologii Eksploatacji Płynów Złożowych. Instytut Nafty i Gazu - Państwowy Instytut Badawczy ul. Lubicz 25 A

31-503 Kraków

E-mail:dorota.kluk@inig.pl
[9] Ossai C. I., Duru U. I., Ossai I. A., Arubi T. I. M.: An Appraisal of Soil Pollution in Oil and Gas Production Environment: A Case Study of Heavy Metals Concentration in Ebocha and Akri Oil Fields. Society of Petroleum Engineers, 2010.

[10] Sekutkowski T., Bartniak M.: Wykorzystanie mikrobiotestu phytotoxkit $w$ wykrywaniu potencjatu allelopatycznego mozgi trzcinowatej (phalaris arundinacea). Journal of Research and Applications in Agricultural Engineering 2009, vol. 54, nr 4, s. 88-93.

[11] Souza R. B., Maziviero T. G., Christofoletti C. A., Pinheiro T. G., Fontanetti C. S.: Soil Contamination with Heavy Metals and Petroleum Derivates: Impact on Edaphic Fauna and Remediation Strategies. INTECH, Soil Processes and Current Trends in Quality Assessment 2013, nr 6, s. 175-203.

[12] Steliga T.: Badania przemystowe biodegradacji weglowodorów ropopochodnych $w$ odpadzie $z$ dołu urobkowego. Przegląd Górniczy 2011, nr 12, s. 107-122.

[13] Steliga T.: Optymalizacja procesu biodegradacji zanieczyszczeń ropopochodnych $w$ zestarzalych odpadach z dołów urobkowych. Gospodarka Surowcami Mineralnymi. PAN 2008, nr 24, s. 87-111.

[14] Steliga T., Kapusta P., Jakubowicz P., Turkiewicz A.: Modelowanie procesu biodegradacji węglowodorów ropopochodnych $w$ zastarzalych odpadach wiertniczych $z$ dołów urobkowych. Wiertnictwo Nafta Gaz 2008, vol. 25, nr 2, s. 667-677.

[15] Steliga T., Kapusta P., Jakubowicz P.: Effectiveness of bioremediation processes of hydrocarbon pollutants in weathered drill wastes. Water, Air, Soil and Pollution 2009, vol. 1-4, s. 211-228.

[16] Steliga T., Kluk D.: Analiza efektywności procesów bioremediacyjnych na terenie dołu urobkowego. Przegląd Górniczy 2007, nr 12, s. 46-53.

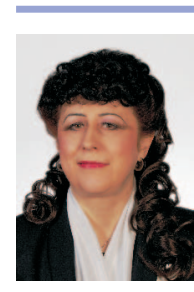

Prof. nzw. dr hab. inż. Teresa STELIGA Kierownik Zakładu Technologii Eksploatacji Płynów Złożowych. Instytut Nafty i Gazu - Państwowy Instytut Badawczy ul. Lubicz 25 A 31-503 Kraków E-mail: teresa.steliga@inig.pl 